Penerapan Strategi Pembelajaran Kooperatif Tipe Team Games Tournament untuk Meningkatkan Respon dan Hasil Belajar PKn Siswa

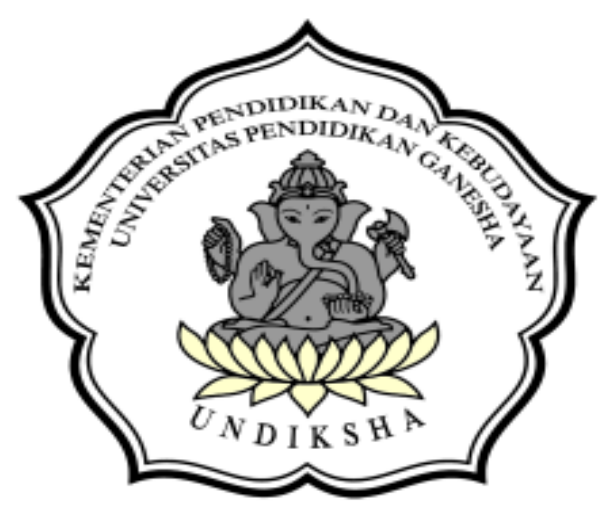

ARTIKEL

Oleh

MADE NIKI ASTITI

0914041075

JURUSAN PENDIDIKAN PANCASILA DAN KEWARGANEGARAAN

FAKULTAS ILMU SOSIAL

UNIVERSITAS PENDIDIKAN GANESHA

SINGARAJA

2013 


\title{
Penerapan Strategi Pembelajaran Kooperatif Tipe Team Games Tournament untuk Meningkatkan Respon dan Hasil Belajar PKn Siswa
}

\author{
Oleh \\ Made Niki Astiti \\ Prof. Dr. Sukadi, M.Pd., M.Ed \\ Dr. I Gusti Ketut Arya Sunu, M.Pd \\ Jurusan Pendidikan Pancasila dan Kewarganegaraan \\ e-mail: nikiastiti@gmail.com
}

\begin{abstract}
ABSTRAK
Penelitian ini bertujuan untuk meningkatkan hasil belajar PKn melalui penerapan strategi pembelajaran Team Games Tournament (TGT), dan mengetahui respon siswa melalui penerapan strategi pembelajaran Team Games Tournament (TGT). Penelitian ini merupakan penelitian tindakan kelas yang dilakukan dalam dua kali siklus tindakan. Subjek penelitian ini adalah siswa kelas VIII F SMP Negeri 5 Singaraja pada semester genap tahun ajaran 2012/2013 yang berjumlah 29 orang. Objeknya meliputi hasil belajar PKn, respon siswa dan penerapan strategi pembelajaran Kooperatif tipe Team Games Tournament (TGT). Data penelitian ini dikumpulkan dengan menggunakan teknik observasi, pemberian tes, dan kuisioner. Selanjutnya data yang telah dikumpulkan dianalisis secara deskriptif kualitatif. Hasil penelitian ini menunjukan bahwa penerapan strategi pembelajaran Team Games Tournament (TGT) dalam pembelajaran PKn pada siswa kelas VIII F SMP Negeri 5 Singaraja, dapat meningkatkan hasil belajar PKn, serta respon siswa tergolong positif.
\end{abstract}

Kata-kata Kunci :Team Games Tournament (TGT), respon dan hasil belajar.

\begin{abstract}
This Study was intended to increase the learning outcome in Civics and the students' response through the application of the learning strategy of Team Games Tournament (TGT). It is an action classroom research conducted in a two-cycle action. The subject of the study included the students of class VIII F of the Public Junior High School 5 Singaraja in the academic year of 2012/2013, totaling 29 student . the object of the study included the learning outcame in Civics the response and the application of learning strategy of Team Games Tournament. The data were collected using the techniques of observation, test, and questionnaire. The data were descriptively and qualitatively analyzed. The result of the study showed that the learning strategy of Team Games Tournament (TGT) could increase the civics learning outcome of the students of class VIII F of the Public Junior High School 5 Singaraja, and that the response given by the students could be categorized as positive.
\end{abstract}

Keyword: Team Games Tournament (TGT) strategy, learning outcome in Civics, Students' response. 


\section{A. PENDAhuluan}

Mata Pelajaran PKn merupakan salah satu mata pelajaran yang wajib diajarkan disekolah menengah pertama. Pembelajaran PKn mempunyai peran yang sangat penting untuk membentuk peserta didik menjadi manusia yang memiliki rasa kebangsaan dan cinta tanah air. Mata Pelajaran Pendidikan Kewarganegaraan merupakan mata pelajaran yang memfokuskan pada pembentukan warga negara yang memahami dan mampu melaksanakan hak-hak dan kewajibannya untuk menjadi warga negara Indonesia yang cerdas, terampil dan berkarakter yang diamanatkan oleh Pancasila dan UUD 1945 (Muhadi, 2011:24).

Keberhasilan dalam pembelajaran PKn tidak hanya ditentukan oleh siswa itu sendiri melainkan ditentukan pula oleh berbagai komponen yang terlibat didalamnya. Salah satunya adalah faktor guru. Kualitas dan keberhasilan pembelajaran sangat dipengaruhi oleh kemampuan dan ketepatan guru dalam memilih dan menggunakan strategi pembelajaran (Solihatin dan Raharjo 2007:1).

Realita di lapangan pada saat sekarang ini lebih cenderung pada pemberian konsep-konsep yang bersifat teoretis. Selain itu guru cenderung menggunakan metode yang belum melibatkan siswa secara aktif dalam proses belajar. Kondisi ini menyebabkan pelajaran PKn kurang bermakna bagi siswa, sehingga hasil belajar siswa menjadi rendah.

Proses pembelajaran seperti itu tampak di kelas VIII F SMP Negeri 5 Singaraja. Sesuai dengan hasil wawancara peneliti dengan guru bidang studi PKn bahwa selain respon siswa yang kurang terhadap proses pembelajaran, siswa dikelas juga belum berani untuk aktif menjawab pertanyaan-pertanyaan terkait materi pembelajaran yang diberikan oleh guru di depan kelas. Secara tidak langsung siswa juga tidak berani untuk menanyakan materi pelajaran yang kurang dimengerti. Tentu saja permasalahan ini berdampak pada rendahnya hasil belajar siswa kelas VIII F SMP Negeri 5 Singaraja. Terbukti pada pelaksanaan ujian tengah semester ganjil tahun 2012, terlihat rata-rata kelas hanya 56,36 sedangkan KKM yang ditetapkan dalam kurikulum sekolah adalah 71.

Melalui penelitian ini penulis mencoba menerapkan Strategi Pembelajaran Team Game Tournament. Permainan dalam Team Game Tournament (TGT) dapat berupa pertanyaan-pertanyaan yang ditulis pada kartu-kartu yang diberi angka. Tiap siswa, misalnya, akan mengambil sebuah kartu yang diberi angka tadi dan berusaha untuk 
menjawab pertanyaan-pertanyaan yang sesuai dengan angka tersebut (Rusman, 2010). Berdasarkan apa yang diungkapkan oleh Slavin (Rusman, 2010) maka strategi pembelajaran kooperatif tipe Team Game Tournament (TGT) memiliki ciri-ciri sebagai berikut: (1) siswa bekerja dalam kelompok - kelompok kecil, (2) games tournament, (3) penghargaan kelompok,

Peneliti yakin dengan menggunakan strategi pembelajaran Team Game Tournament dapat mewujudkan respon positif dan meningkatkan hasil belajar PKn siswa. Melalui strategi pembelajaran Team Game Tournament, akan mampu memberikan suasana pembelajaran yang santai dan menyenangkan tetapi siswa dapat memahami materi pembelajaran melalui tournament-tournament yang diterapkan. Diharapkan melalui strategi pembelajaran Team Game Tournament dapat meningkatkan pemahaman siswa pada mata pelajaran PKn, serta semangat kebersamaan dan saling membantu dalam menguasai materi PKn, sehingga siswa dapat meningkatkan hasil belajar yang optimal terhadap mata pelajaran PKn.

Dari pemaparan di atas adapun tujuan yang ingin dicapai dalam penelitian ini yaitu : (1) Untuk meningkatkan respon positif siswa dalam mengikuti pembelajaran dengan penerapan strategi Pembelajaran Team Game Tournament (TGT). (2) Untuk meningkatkan hasil belajar siswa Kelas VIII F SMP Negeri 5 Singaraja dalam mata pelajaran PKn. (3) Untuk mengetahui kendala-kendala apakah yang dihadapi dalam penerapan strategi pembelajaran Team Game Tournament (TGT) dan alternatif pemecahan masalahnya.

\section{B. METODE PENELITIAN}

Penelitian ini menggunakan rancangan penelitian tindakan kelas (PTK) yang dilaksanakan untuk meningkatkan respon dan hasil belajar siswa. Penelitian tindakan kelas ini adalah suatu penelitian terhadap kegiatan belajar berupa sebuah tindakan, yang sengaja dimunculkan dan terjadi dalam sebuah kelas secara bersama (Arikunto, 2009: 3). Penelitian tindakan kelas (PTK) ini dilaksanakan dalam dua siklus, masing-masing siklus terdiri dari beberapa tahapan yaitu perencanaan, pelaksanaan tindakan, observasi/evaluasi, dan refleksi tindakan (Iskandar, 2008). Alur pelaksanaan Tindakan Kelas dua siklus diadaptasi dari Sukardi tahun 2004. Subjek dalam penelitian tindakan 
kelas ini adalah siswa kelas VIII F SMP Negeri 5 Singaraja. Penelitian ini dilakukan pada semester genap tahun pelajaran 2012/2013. Objek dari penelitian tindakan kelas ini adalah (1) respon siswa terhadap pelaksanaan strategi pembelajaran Team Game Tournament (TGT), (2) hasil belajar siswa kelas VIII F SMP Negeri 5 Singaraja, (3) pelaksanaan pembelajaran PKn. Teknik analisis data dalam penelitian ini yaitu teknik analisis data kuantitatif dan kualitatif (Iskandar, 2008).

\section{Hasil Penelitian}

Pada awal kegiatan, peneliti melakukan pendekatan dengan guru PKn dan siswa kelas VIII F SMP N 5 Singaraja. Kegiatan awal dilakukan bertujuan untuk menyamakan persepsi, sikap, dan tindakan antara peneliti, guru PKn, dan para siswa tentang langkahlangkah pembelajaran PKn yang akan dilakukan agar mencapai tujuan penelitian secara utuh. Kegiatan awal dilaksanakan sekali pertemuan. Berdasarkan pertemuan awal tersebut kemudian disepakati oleh peneliti dan guru untuk melaksanakan tindakan dalam penelitian ini dengan penyempurnaan lebih lanjut. Pelaksanaan tindakan selanjutnya dilakukan sesuai jadwal yang telah ditetapkan di sekolah yaitu hari kamis, pukul 07.5509.15 wita.

Pada perencanaan siklus I yaitu melakukan analisis kurikulum untuk menentukan standar kompetensi, kompetensi dasar dan menyusun silabus, membuat RPP strategi pembelajaran kooperatif tipe TGT, menyiapkan media pembelajaran, dan menyiapkan kartu soal. Materi pada pertemuan siklus I yaitu makna kedaulatan rakyat, macam-macam teori kedaulatan, kedaulatan negara Indonesia, dan menganalisis perkembangan kedaulatan rakyat di Indonesia.

Pembelajaran dimulai dengan presentasi kelas, kemudian dilanjutkan dengan pemaparan materi dimana peneliti mengajukan beberapa pertanyaan agar siswa terlibat aktif dalam pembelajaran namun pada siklus satu ini hanya beberapa siswa saja yang berani menanggapi pertanyaan dari peneliti. Peneliti terus memberikan motivasi kepada siswa untuk berani menjawab pertanyaan-pertanyaan yang diajukan oleh peneliti. Pembelajaran dilanjutkan pada pembentukan kelompok. Siswa dibagi menjadi 5 kelompok belajar yang terdiri dari 5-6 orang dengan anggota heterogen. Dalam kelompok belajarnya siswa mendiskusikan materi pembelajaran bersama anggota kelompoknya. Bagi siswa yang kurang mengerti dapat bertanya dengan anggota kelompoknya yang 
sudah mengerti namun pada siklus I ini, siswa belum melakukan diskusi kelompok dengan baik. Seperti terlihat pada gambar dibawah ini.

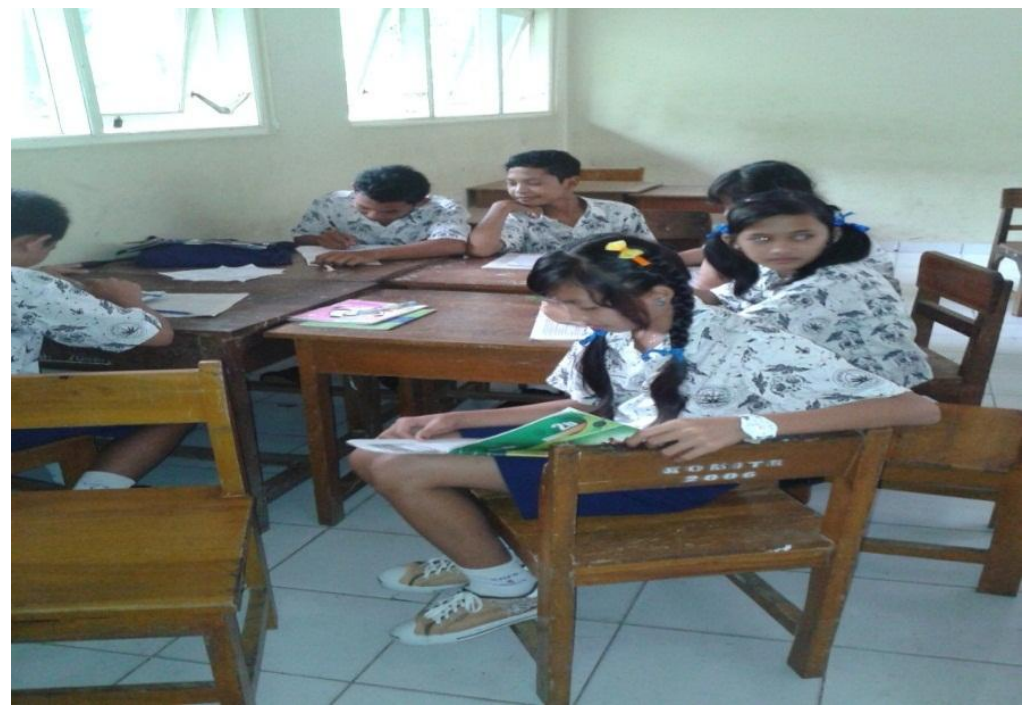

\section{Gambar 1. Diskusi kelompok}

Kemudian peneliti mengadakan tanya jawab seputaran materi yang didiskusikan oleh siswa. Tahap selanjutnya yaitu turnamen. Pada tahap ini siswa kembali dibagi menjadi 4 kelompok dengan anggota kelompok yang memiliki kemampuan akademik hamper sama menuju meja turnamen. Cara bermain serta aturan permainan dijelaskan oleh peneliti. Pada akhir turnamen siswa mengumpulkan poin yang mereka peroleh saat tuenamen dan menghitung perolehan skor yang diperoleh anggotanya selama turnamen.

Pada tahap akhir dilakukan kegiatan penutup yaitu, peneliti bersama siswa menyimpulkan pelajaran kemudian peneliti memberikan pos tes kepada siswa dan tindak lanjut berupa pekerjaan rumah. Berdasarkan hasil tes akhir siklus I, rata-rata kelas mencapai 71,44\% yang berada pada kategori belum tuntas sedangkan ketuntasan belajar secara klasikal mencapai 51,72\%. Ini berarti belum mencapai kriteria keberhasilan tindakan yaitu $75 \%$.

Berdasarkan hasil observasi maka didapat kendala-kendala sebagai berikut: (1) Pada pertemuan pertama, masih terdapat beberapa siswa yang kurang antusias dalam penggunaan strategi pembelajaran Team Games Tournament di kelas. (2) siswa masih ribut dalam pembentukan kelompok dan belum mampu memanfaatkan waktu seefisien mungkin sehingga berpengaruh pada waktu jam pelajaran yang tersedia. (3) Siswa masih bingung dalam permainan akademik Team Games Tournament yang diterapkan guru 
karena hal tersebut baru pertama kali dilakukan. (4) Waktu yang tersedia tidak mencukupi karena waktu lebih lama terlewatkan saat menjelaskan langkah-langkah pembelajaran dengan strategi pembelajaran Team games Tournamaent (TGT), saat pembentukan kelompok, dan saat berlangsungnya tanya jawab setelah diskusi kelompok selesai. (5) Siswa belum melaksanakan diskusi kelompok dengan serius, masih ada beberapa siswa yang lain-lain saat diskusi kelompok.

Pada perencanaan siklus II yaitu berdasarkan hasil refleksi pada siklus satu maka peneliti lebih mengupayakan pembelajaran yang lebih efesien lagi untuk meningkatkan hasil belajar siswa. Upaya-upaya tersebut sebagai berikut: (1) Siswa dijelaskan kembali mengenai sistem penilaian yang dilakukan, baik melalui pos tes dan tes akhir siklus untuk memperoleh hasil belajar siswa. Diharapkan dengan dijelaskan sistem penilaian ini maka siswa akan termotivasi untuk aktif secara individu maupun kelompok. (2) Agar menjaga kondisi kelas tetap tertib maka peneliti dan guru mengawasi dengan baik siswa dalam melakukan tournament dan selalu memberi peringatan saat ada salah satu siswa yang ribut. Sehingga dapat mengendalikan kondisi kelas. (3) Pada siklus I diadakan diskusi kelompok dan membuat laporan hasil diskusi. Kemudian peneliti mengadakan tanya jawab kepada siswa, namun pada siklus II tidak diadakan lagi tanya jawab tersebut untuk lebih mengefesienkan waktu. (4) Peneliti lebih meningkatkan pengawasan saat diskusi kelompok berlangsung agar tidak ada siswa yang lain-lain. Dalam perencanaan siklus II peneliti juga menyiapkan kartu soal. Materi pembelajaran pada siklus II yaitu sistem pemerintahan, peran lembaga negara sebagai pelaksanaan kedaulatan rakyat dan hubungan partai politik dengan kedaulatan rakyat.

Pembelajaran dimulai dengan presentasi kelas, kemudian peneliti memaparkan materi dan siswa diberikan pertanyaan-pertanyaan mengenai materi, siswa sudah antusias menjawab pertanyaan-pertanyaan yang diberikan oleh guru, dan siswa sudah berani menanggapi pernyataan siswa yang dianggap kurang tepat. Kemudian lanjut pada pembentukan kelompok, siswa berdiskusi dengan anggota kelompoknya mengenai soalsoal yang ada di LKS. Siswa sudah melakukan kerja kelompok dengan bak seperti terlihat pada gambar dibawah ini. 


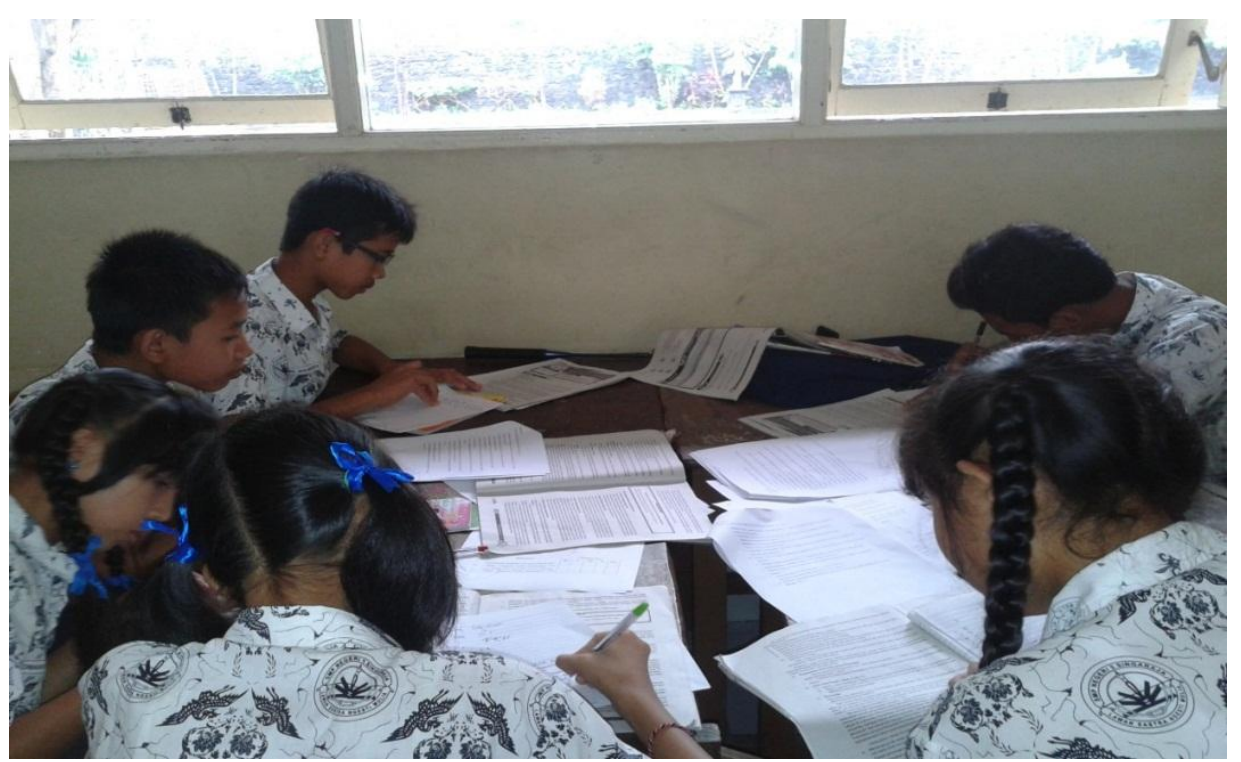

Gambar 02. Diskusi Kelompok

Dalam gambar di atas siswa sudah terlihat melaksanakan proses diskusi dengan baik. Masing-masing siswa mencari jawaban mengenai soal yang ada di LKS, setelah semua soal terjawab maka siswa berdiskusi mencocokan jawaban satu sama lain. Kemudian saat pelaksanaan turnamen dimulai, siswa menuju meja turnamen, siswa bertanding dengan siswa-siswa yang memiliki kemampuan akademik hampir sama. Siswa sudah aktif menjawab pertanyaan-pertanyaan maupun menantang jawaban pemain.

Berdasarkan hasil analisis tes akhir siklus II maka diperoleh rata-rata 76,08\% yang berada pada kategori tuntas, sedangkan ketuntasan belajar secara klasikal mencapai $82,75 \%$. Ini berarti sudah memenuhi target minimal yang telah ditentukan yaitu $75 \%$.

Berdasarkan hasil analaisis data secara klasikal mendapat skor respon sebesar 1.260 dari 29 siswa, sehingga rata-ratanya diperoleh skor 43,45. Dengan demikian respon siswa terhadap strategi pembelajaran Team Games Tournament (TGT) berada pada kategori positif.

Adanya peningkatan hasil belajar siswa dengan penerapan strategi pembelajaran Team Games Tournament (TGT) pada siklus II dapat diamati pula dari hal-hal yang berkaitan dengan kegiatan pembelajaran sebagai berikut: (1) Di awal pembelajaran, siswa sudah berani untuk menjawab pertanyaan-pertanyaan yang guru berikan, kemudian siswa sudah mampu menyangga jawaban dari siswa lain yang di anggap kurang tepat. Jadi 
kegiatan siswa sudah aktif dalam kegiatan pembelajaran. (2) Dalam kegiatan kelompok, siswa sudah mampu berdiskusi dengan baik, tidak ada lagi siswa yang lain-lain atau tidak memperhatikan diskusi kelompok, tidak ada lagi siswa yang bekerja sendiri dalam kelompoknya, melainkan saling berdiskusi untuk menjawab soal yang diberikan oleh guru. Kemudian saat guru memberikan beberapa pertanyaan mengenai materi yang didiskusikan, siswa pun sudah antusias menaikan tangannya untuk menjawab. (3) Pada saat pembelajaran berakhir, secara umum siswa sudah mampu membuat kesimpulan berdasakan materi pembelajaran yang telah dibahas dan didiskusikan. (4) pembelajaran yang dilakukan sesuai dengan waktu yang telah disediakan.

\section{Pembahasan}

Berdasarkan hasil penelitian yang telah dilaksanakan pada siklus I dan siklus II dengan penerapan strategi pembelajaran Team Games Tournament (TGT) di kelas VIII F SMP Negeri 5 Singaraja telah menunjukan bahwa adanya peningkatan hasil belajar PKn. Penelitian ini didukung oleh hasil penelitian yang relevan. Penerapan model pembelajaran tipe TGT dapat meningkatkan hasil belajar IPA siswa kelas V SD 3 TingaTinga, hasil belajar siswa dan persentase hasil belajar secara klasikal telah mencapai kriteria keberhasilan yaitu hasil belajar siswa melebihi dari KKM yang ditetapkan (Sukaerawati, 2011:86). Penerapan model pembelajaran tipe Team Games Tournament dapat meningkatkan hasil belajar Bahasa Inggris siswa kelas IV SD No. 1 Baktiseraga, rata-rata hasil belajar siswa melebihi dari KKM yang ditentukan (Adistia, 2011:47). Melalui model pembelajaran kooperatif tipe TGT pada siswa kelas X A Akuntansi SMK Negeri 1 Singaraja, hasil belajar siswa dalam mata pelajaran PKn meningkat sedangkan respon siswa juga berada pada kategori baik (Sandyagraha, 2012:88). Dari hasil penelitian diatas maka dapat disimpulkan bahwa model pembelajaran TGT dapat meningkatkan hasil belajar siswa.

Team Games Tournament pada mulanya dikembangkan oleh David De Vries dan Keith Edwards, TGT merupakan model pembelajaran yang dapat meningkatkan motivasi siswa dalam mengembangkan aktifitas dan inisiatif dalam belajar sebab dalam TGT siswa memainkan permainan dengan anggota-anggota tim yang lain untuk memperoleh tambahan poin untuk skor tim mereka (Slavin, 2008:13). Team game tournament 
mengoptimalkan penguasaan materi melalui kompetisi dan juga kooperasi. Pada pembelajaran TGT, para murid yang berlevel kemampuan berbeda-beda bekerjasama dalam tim belajar untuk meninjau materi penting serta membantu sama lain menopang kesenjangan-kesenjangan dalam pembelajaran. Para murid kemudian meninggalkan timtim belajar mereka untuk berkompetisi dengan para murid dari tim-tim belajar lain dalam suatu turnamen akademis. Saat berlangsungnya turnamen ini, para murid memperoleh poin-poin bagi tim mereka dengan menjawab pertanyaan-pertanyaan dan menantang jawaban-jawaban para pemain lain. Jadi, tim-tim belajar yang paling aktif yang berkinerja paling efektif dalam menyiapkan semua anggotanya hingga berhasil dalam kompetisi dan memperoleh poin terbesar (Harvey, 2012:61). Siswa akan memberikan respon terhadap pembelajaran melalui kompetisi yang diadakan dalam pembelajaran tipe TGT.

TGT menggunakan model penskoran berbasis motivasi, saat berlangsungnya turnamen para pemain akan menjawab pertanyaan-pertanyaan yang didapat. Para penantang juga akan memberi jawabannya. Melalui pemberian skor kepada siswa yang dapat menjawab pertanyaan maka siswa akan termotivasi untuk mau belajar sehingga siswa akan terlibat aktif dalam turnamen yang nantinya akan dapat meningkatkan hasil belajar siswa (Harvey, 2012:63).

Berdasarkan uraian di atas, maka cukup beralasan untuk menarik suatu kesimpulan untuk mendukung kebenaran hipotesis sebelumnya yaitu jika pembelajaran Tipe Team Games Tournament (TGT) dapat meningkatkan respon dan hasil belajar PKn siswa di kelas VIII F SMP Negeri 5 Singaraja.

Dari hasil penelitian ini ditemukan kelebihan dari strategi pembelajaran Team Games Tournament (TGT) tersebut antara lain: Siswa lebih aktif dalam pembelajaran karena dalam penerapan strategi pembelajaran tipe team games tournament (TGT) pembelajaran berpusat pada siswa sehingga siswa dituntut untuk aktif baik dalam diskusi kelompok, kerjasama kelompok dan dalam turnamen, sedangkan guru hanya sebagai fasilitator saja. Jadi siswa itu benar-benar menggali pengetahuan yang dimiliki karena termotivasi untuk terlibat aktif dalam turnamen yang dilakukan. Hubungan sosial siswa yang satu dengan yang lainnya menjadi lebih baik karena dalam kelompok siswa dituntut untuk bekerjasama dalam memahami materi pelajaran. 


\section{PENUTUP}

Berdasarkan hasil penelitian yang telah dilakukan, maka dapat disimpulkan beberapa hal yaitu: pertama, penerapan strategi pembelajaran Team Games Tournament (TGT) dalam pembelajaran PKn dapat meningkatkan hasil belajar PKn siswa kelas VIII F SMP Negeri 5 Singaraja. Kedua melalui hasil angket respon yang diberikan kepada siswa, maka siswa kelas VIII F SMP Negeri 5 Singaraja memiliki respon positif terhadap strategi pembelajaran Team Games Tournament (TGT) dalam pembelajaran PKn. Ketiga terdapat beberapa kendala-kendala yang dihadapi peneliti saat menerapkan strategi pembelajaran Team Games Tournament (TGT) pada siklus I, namun berdasarkan hasil refleksi siklus I dan diadakan berbagai upaya perbaikan, maka pada siklus II kendalakendala tersebut dapat diminimalisir.

\section{DAFTAR PUSTAKA}

Arikunto. 2009. Penelitian Tindakan Kelas. Jakarta: Bumi Aksara

Iskandar. 2008. Metodologi Penelitian Pendidikan dan Sosial (Kuantitatif dan Kualitatif). Jakarta: Gaung Persada Press.

Kumbara, Adistia. 2011. Penerapan Model Pembelajaran Kooperatif Tipe Team Games Tournament (TGT) untuk Meningkatkan Aktivitas dan Hasil Belajar Bahasa Inggris Siswa Kelas IV SD No. 1 Baktiseraga Kecamatan Buleleng Kabupaten Buleleng. Undiksha

Muhadi. 2011. Penelitian Tindakan Kelas. Yogyakarta: Shira Media.

Rusman. 2010. Model-Model Pembelajaran. Bandung: Mulia Media Pers

Sandyagraha. 2012. Penerapan Model Pembelajaran Kooperatif tipe Team games Tournament (TGT) Terhadap Tingkat Keaktifan dan Hasil Belajar PKn Siswa Kelas X A Akuntansi SMK Negeri 1 Singaraja. Undiksha

Slavin, E. 2005. Cooperatif Learning; Teori, Riset dan Praktik. Bandung: Nusa Media

------. 2008. Cooperative Learning. Bandung : Penerbit Nusa Media

Sukaerawati. 2011. Penerapan Pembelajaran Kooperatif Tipe Team Game Tournament (TGT) untuk Meningkatkan Hasil Belajar IPA pada Siswa Kelas V Semester I SD N 3 Tinga-Tinga Kecamatan Gerokgak Kabupaten Buleleng. Undiksha 
Solihatin, Etin dan Raharjo. 2007. Cooperative Learning: Analisis Model Pembelajaran IPS. Jakarta: Bumi Aksara.

Sukardi. 2004. Metodologi Penelitian Pendidikan. Jakarta: Bumi Aksara

Harvey. 2012. Strategi - strategi Pengajaran. Jakarta : PT. Indeks 